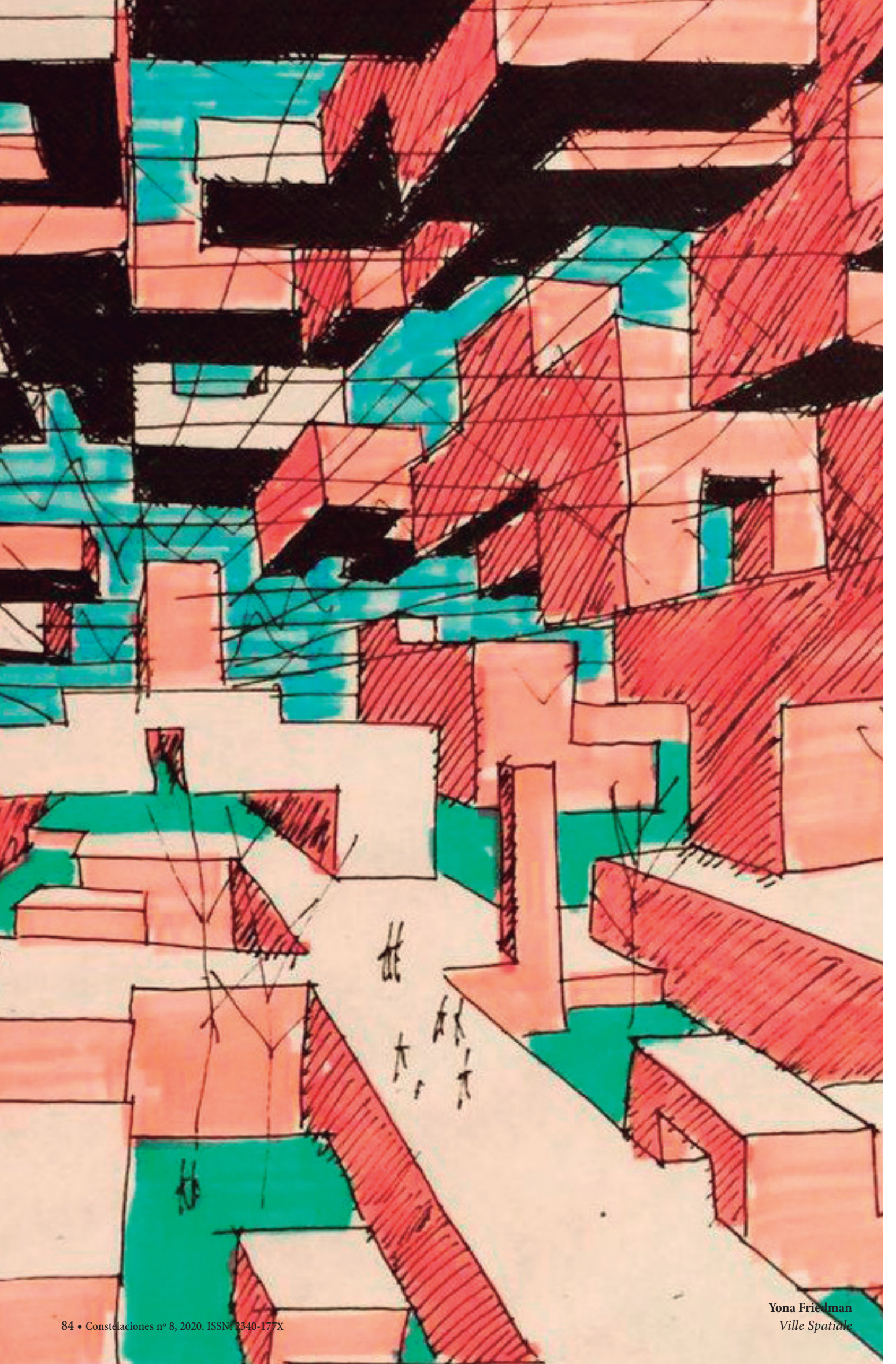




\title{
Manuel de las Casas, Casa Moro (1963-1971). La planta al bies Manuel de las Casas, Moro House (1963-1971). An Oblique Plan
}

\author{
José Ramón González de la Cal, Josefa Blanco Paz \\ UCLM, Escuela de Arquitectura de Toledo \\ Traducción Translation Estudio MH10
}

Palabras clave Keywords

Manuel de las Casas, Javier Seguí, Santiago Hernández, Casa Pedro Moro, arquitectura española, brutalismo, organicismo Manuel de las Casas, Javier Seguí, Santiago Hernández, Pedro Moro's House, Spanish Architecture, brutalism, organic architecture.

\begin{abstract}
Resumen
En la arquitectura de Manuel de las Casas (Talavera de la Reina 1940 Madrid 2014) hay una clara invariante de proyecto que se manifiesta de forma temprana ya desde su opera prima, la Casa Moro (1963-1971), el dominio de la traza de la planta como herramienta de proyecto.

La Casa Moro solo necesita de la planta, no tiene alzado, la sección es el acomodo al suelo, que es la planta. Una primera obra que delata unos intereses compositivos influenciados por el 'organicismo', el 'brutalismo' y la certeza compositiva que asegura la racionalidad de la construcción vernácula. Es un trazado de un sistema de fábricas de muros de carga paralelos, un pentagrama de variaciones de crujías de vano corto, donde la diagonal unas veces amplia y otras acorta las distancias. Una arquitectura que confía en la construcción como soporte de la composición, invariante que acompañará a sus mejores obras, proyectadas desde el gobierno de la planta, que aparece casi como un manifiesto ya en esta primera obra.
\end{abstract}

\section{Abstract}

In all the architecture by Manuel de las Casas (Talavera de la Reina 1940 Madrid 2014) we can find a common invariant that will be present in a very clear way since his first project: Moro House (1963-1971). This invariable is the ability to use the drawing of the plan as the main tool for all the project. The Moro House is a clear example of this idea. It doesn't have an elevation, it only needs the plan. The section is created as it touches the floor, becoming the plan as well. This debut construction unveils its influences on its composition: Organic Architecture, Brutalism and the fact that this composition guarantees the rationalism of vernacular construction. Its outline is based on a system of parallel load-bearing walls, a pentagram created by varying the distance between these walls so that the diagonal sometimes makes distances seem longer and other times shorter. An architecture that is confident with its construction as the key of the composition. This idea will be always present, especially in his best projects, and from the beginning of his career: The plan has the leading role. 
La planta es una sección horizontal, difícilmente podríamos afirmar que la sección es una planta vertical. La planta realiza el acuerdo con el suelo y con el horizonte, la sección lo hace con el cénit inalcanzable. La planta narra y describe la arquitectura terrenal. Hay arquitecturas a las que les basta con la traza a la altura de la vista para hacerse comprender, para hacerse visibles. La planta es a la arquitectura como la partitura a la música. La planta es invisible, un código abstracto de organización espacial.

En la obra de Manuel de las Casas es constante ya desde su opera prima (1) la Casa Moro, (Fig. 1) Talavera de la Reina 1963-1971, el dominio de la traza como sistema de pensamiento arquitectónico. Una obra que sintetiza una manera de hacer arquitectura, donde el instrumento de la planta aúna: construcción, racionalidad y contemporaneidad alrededor de la materia alzada, para dar cobijo al hombre. (Fig. 2)
Fig. 1. Casa Moro. Planta, plano n. 4 del proyecto de ejecución, abril 1967. Archivo Manuel de las Casas.

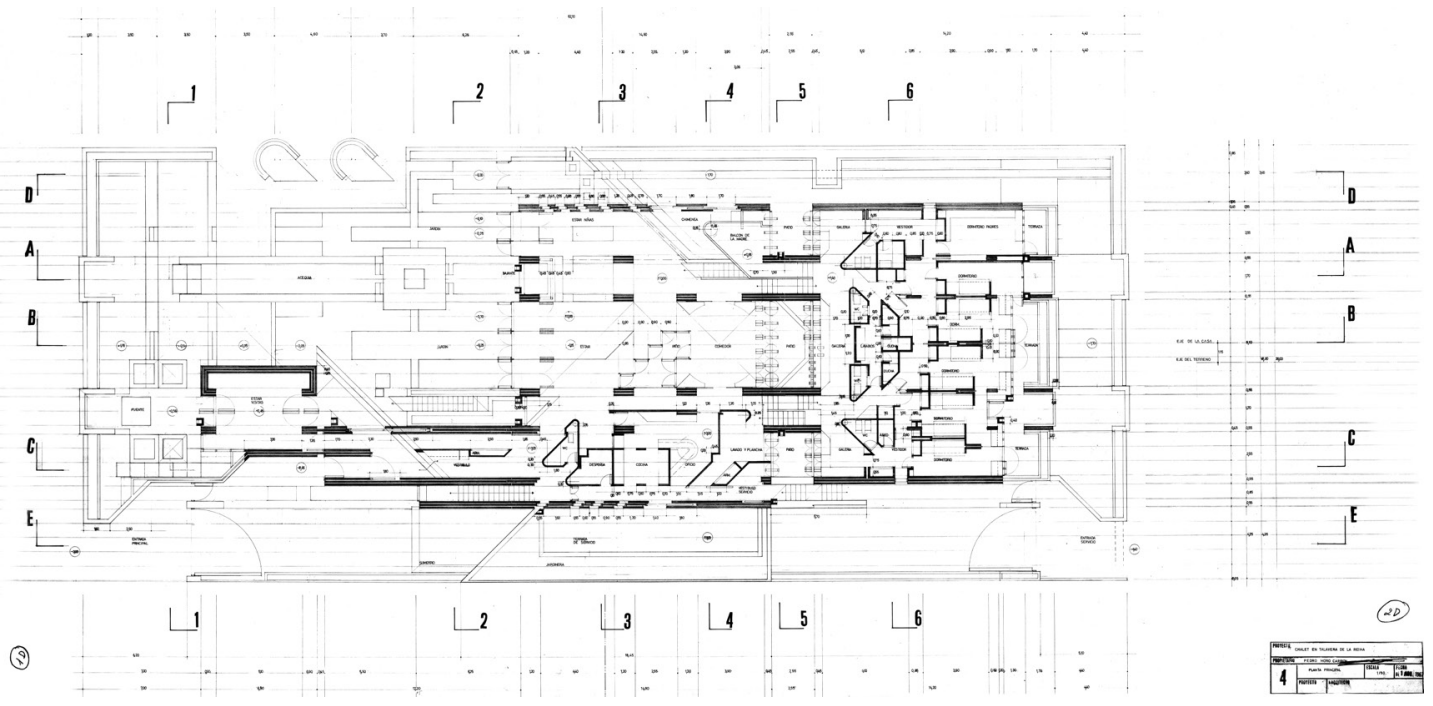

The plan is a horizontal section, but we can doubtfully affirm that a section is a vertical plan. The plan connects the floor with the horizon; the section connects it to an unreachable zenith. The plan narrates and describes the architecture and its connection to the earth. Some architectures only need the trace at eye level to be understood, to be visible. The plan is to architecture what the music sheet is to music. The plan is invisible, an abstract code of the spatial organization.

In Manuel de las Casas' work it is constant since his debut, (1) Moro House, (Fig. 1) at Talavera de la Reina 1963-1971, the control he has of the trace as a way of architectural thinking. A project that synthesizes a way of making architecture, where the plan is an instrument to connect construction, rationalism and contemporaneity around the elevated matter, to give shelter to humans. (Fig. 2)

[Scene] Nueva Forma, Ideological Context. With the boost of the 20th Century vanguards, architecture starts to break through the Academy. The first demonstration of this change in thought is the Proto-Rationalism, inherited from a Neoclassicism that is free of ornaments. The ideal of the Modern European Movement, that relies on the artistic vanguards and Bauhaus, will open to a new way that culminates in a premature exile to the American continent, now known as the International Style. Over the ruins of war, modernity will still look for an opportunity in the 50s. In this period, some will get close to it, sometimes in a natural way and others as a modern revision of tradition, accepting the failure of the utopian ideals of the Modern Movement and its forms. 
[Medio] Nueva Forma, contexto ideológico. Con el impulso de las vanguardias, en los inicios del siglo xx, la arquitectura comienza el camino de ruptura con la Academia. La primera manifestación del cambio de pensamiento será el protoracionalismo, heredado de un neoclasicismo libre de vestimentas. El ideal moderno centroeuropeo, alentado por las vanguardias artísticas y decantado en la Bauhaus entre los años veinte y treinta, alumbra un nuevo camino que culmina en un exilio prematuro en el continente americano, etiquetado como Estilo Internacional. Sobre las ruinas de la guerra, la modernidad aún buscará en los años 50 su oportunidad, cuando algunos se acercarán, unas veces al orden natural y otras a una revisión moderna de la tradición; aceptando ya el fracaso de los utópicos ideales del Movimiento Moderno y de sus formas.

A la península, bien por su condición periférica, bien por el fracaso de los intentos de modernización, truncados por la contienda incivil, todos estos cambios de dirección del pensamiento llegarán siempre con décadas de retraso. La inflexión de superación del racionalismo hacia lo orgánico que ya desde 1944 defendía Bruno Zevi (2) desde la APAO (Associazione per l'Architettura Organica), proponiendo a Wright como pionero y destacando a Aalto y Asplund en Europa como ejemplos de la nueva arquitectura moderna, tendrá su eco en España en 1958, con el Pabellón de la Exposición de Bruselas de Corrales y Molezún (1958). Son los sesenta, años de crecimiento económico impulsado por los tecnócratas Planes de Desarrollo. Incipiente apertura ideológica y mejora económica que necesita de nuevas formas, que evidencien el abandono del ascetismo formal del racionalismo y el abrazo al nuevo ideal: la complejidad orgánica. Y es en este contexto de ideal orgánico, de inicios de los sesenta, cuando surge una nueva generación de arquitectos, consagrada una década después, en 1978, en el artículo "28 arquitectos no numerarios" de Rafael Moneo. (3) Generación alumbrada por Antonio Fernández Alba, que con su llegada en 1961 a la Escuela de Madrid y con el Premio Nacional de Arquitectura de 1963 por el Convento del Rollo, se convertirá en el guía del cambio de rumbo hacia el organicismo. Cambio cuya crónica y soporte teórico construirá Juan Daniel Fullaondo en la revista Nueva

These changes will reach the Spanish Peninsula with decades of delay, perhaps for its peripheral condition or maybe because of the failure in the attempts of modernization, interrupted by the 'uncivil' war.

The turning point where Rationalism is overtaken by the organic architecture that already in 1944 Bruno Zevi (2) would stand up for from the APAO (Associazione per l'Architettura Organica), suggesting Wright as a pioneer and Aalto and Asplund in Europe as examples of the new modern architecture, will reach Spain in 1958, with the pavilion of Corrales and Molezún (1958) in the Brussels Exhibition.

We are in the 60s, years of economic growth, driven by de technocratic Planes de Desarrollo. Emergent ideological opening that needs new ways. These ways leave aside the formality of rationalism and embrace the new ideal: The organic complexity. And, in this context, a new generation of architects appear, a generation that will be acclaimed in 1978, in the article by Rafael Moneo (3) "28 arquitectos no numerarios" ("28 not Numerary Architects"). The father of this generation is Antonio Fernández Alba. He will turn to be the guide in this change since his arrival, in 1961, to Madrid's School of Architecture and later on in 1963 when he receives the National Architecture Award for his work in the Rollo Convent. This change will have its theoretical basis and chronicle in Juan Daniel Fullaondo's Nueva Forma magazine (1966-1975). Two events will confirm the drift to the organicism that started in the Brussels Exhibition: First, the competition for Madrid's Opera House (1964), where the youngest will show their clear support, graphically, to this movement. With no prize but pointed out by the critics, the proposal of Manuel de las Casas, Santiago Hernández and 
Forma (1966-1975). Dos hechos confirmarán la deriva iniciada en Bruselas hacia el organicismo en España, el Concurso de la Ópera de Madrid (1964), donde los más jóvenes, algunos de los que tomarán el relevo en la Escuela de Madrid, se manifestarán, al menos, en clave gráfica seguidores del organicismo. No premiada, pero sí destacada por la crítica, será la propuesta de Manuel de las Casas, Santiago Hernández y Seguí, apadrinados por Carvajal. (Fig. 3) Y por otro lado estará Torres Blancas (1961-1968), de Sáenz de Oíza, tótem de las formas orgánicas.

La Casa Moro se ubica en el tránsito de la arquitectura española del racionalismo hacia el organicismo. El brutalismo expresivo de la arquitectura muraria de hormigón y ladrillo de las Casas Jaoul (1954) y la organización de muros paralelos de la Casa Sarabhai (1955), de Le Corbusier, (4) (Figs. 4-5) concurren también en la Casa Moro. Referencias intelectuales modernas que se encuentran en esta obra con una construcción vernácula sofisticada, donde la figura del padre -aparejador- Manuel de las Casas Rementería, colaborador de Moya, Cabrero y Aburto, contagiará la obra de la disciplina de la construcción clásica, derivada de la virtud y la necesidad de la construcción de postguerra, dando al proyecto un oficio y madurez tectónica difícil de imaginar en un recién titulado.

Pero esta línea orgánica pronto será abandonada. Los proyectos inmediatos a la Casa Moro, el colegio artefacto en Medina del Campo (1969), la Residencia de Internas (1975), hasta la manzana de Cabeza del Moro (1977), serán ejercicios de la vuelta al rigor y la disciplina escueta de las formas. Sin embargo, ya desde la Casa Moro, permanecerá la subordinación del proyecto al orden constructivo de la planta como una invariante en la obra de Manuel de las Casas. En sus trabajos posteriores los excesos formales quedarán reducidos a anécdotas, a breves citas figurativas en el alzado (como sucede en la Casa Magariños, 1977) que, con el tiempo, se convertirán en miradas de reojo al Postmodern, al que se entregaron la mayoría de los arquitectos tras el tardoorganicismo español de la década 60-70. Otros saltaron directamente a la bacanal deconstructivista que, de manos de Fullaondo, acabó con Nueva Forma

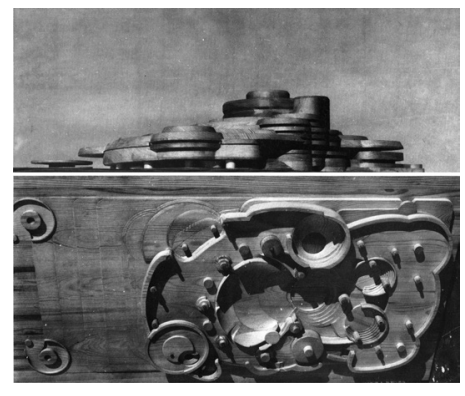

Fig. 3. Maqueta concurso Ópera de Madrid, propuesta de Manuel de las Casas y Javier Seguí. Publicada en KAIN 1988, n. 3, p. 3.

Javier Seguí sponsored by Carvajal, (Fig. 3) will be key. The second event will be the principal symbol of organic forms in Madrid: Torres Blancas, by Sáenz de Oíza (1960-67).

Moro's house is placed between Rationalism and Organicism in Spanish architecture. There is also an influence from the expressive Brutalism in the mixture of concrete and bricks of the Jaoul House (1954) and the parallel organization of walls of the Sarabhai House (1955), (4) (Figs. 4-5) from Le Corbusier. Intellectual and modern references appear in this project with a vernacular but sophisticated construction, where the figure of the technical architect, Manuel de las Casas Rementería (father), working together with Moya, Cabrero and Aburto, will pass on to the project their classical way of working, their virtue and their skills acquired with their experience in postwar construction, giving it a purpose and tectonic maturity that normally doesn't match with the work of a beginner.

But the organic path will soon be abandoned. The projects that come just after the Moro House, from the School in Medina del Campo (1969), the Interns Residence (1975), to the Cabeza del Moro's block (1977), will be exercises that prove the return to exactitude and simple discipline of forms. Nevertheless, since the Moro House, the subordination of the project to the constructive order of the plan will always be a constant in the work of Manuel de las Casas. In his following projects, formal excess will be reduced to anecdotes, to small figurative quotes in the facade (for example, the Magariños House, 1977), that with time will turn to a sideways look to the popular Postmodernism that many architects succumbed to after the late Spanish Organicism of the 60s and the 70s. Others jumped directly to a Deconstructivist bacchanal that, led by 
y embriagó a finales de los 80 a la Escuela de Madrid; o hacia el High Tech, coincidiendo con la salida de la ETSAM de Oíza. Estas corrientes académicas no encontrarían su referente construido, unas por ser meras elucubraciones gráficas, otras por el subdesarrollo tecnológico e industrial de España. Frente al fracaso de ambas se impondrá en la Escuela de Madrid la disciplina del proyecto trazado en planta, como método académico de proyectar, defendido por muchos de aquellos que tomaron el relevo en los 60, la retaguardia de los ideales modernos de principio de siglo.

Ensanche burgués. La Casa Moro se sitúa en Talavera de la Reina, Toledo, en la Avenida Extremadura n. 16, antigua Nacional V que lleva desde Madrid a Lisboa. Talavera surge como posición estratégica, paso del Tajo en las comunicaciones este-oeste, lugar idóneo para el comercio. Las ferias de mayo y septiembre surgieron vinculadas al mercado de ganado y aún se seguían celebrando a mediados del siglo xx en los Jardines del Prado, frente a la
Fig. 4. Casas Jaoul, Le Corbusier (1954). Archivo FLC/ADAGP.

Fig. 5. Casa Sarabhai, Ahmedabad, Le Corbusier (1955). Planta. Publicada en Le Corbusier Oeuvre complète 1952-57, p. 118.
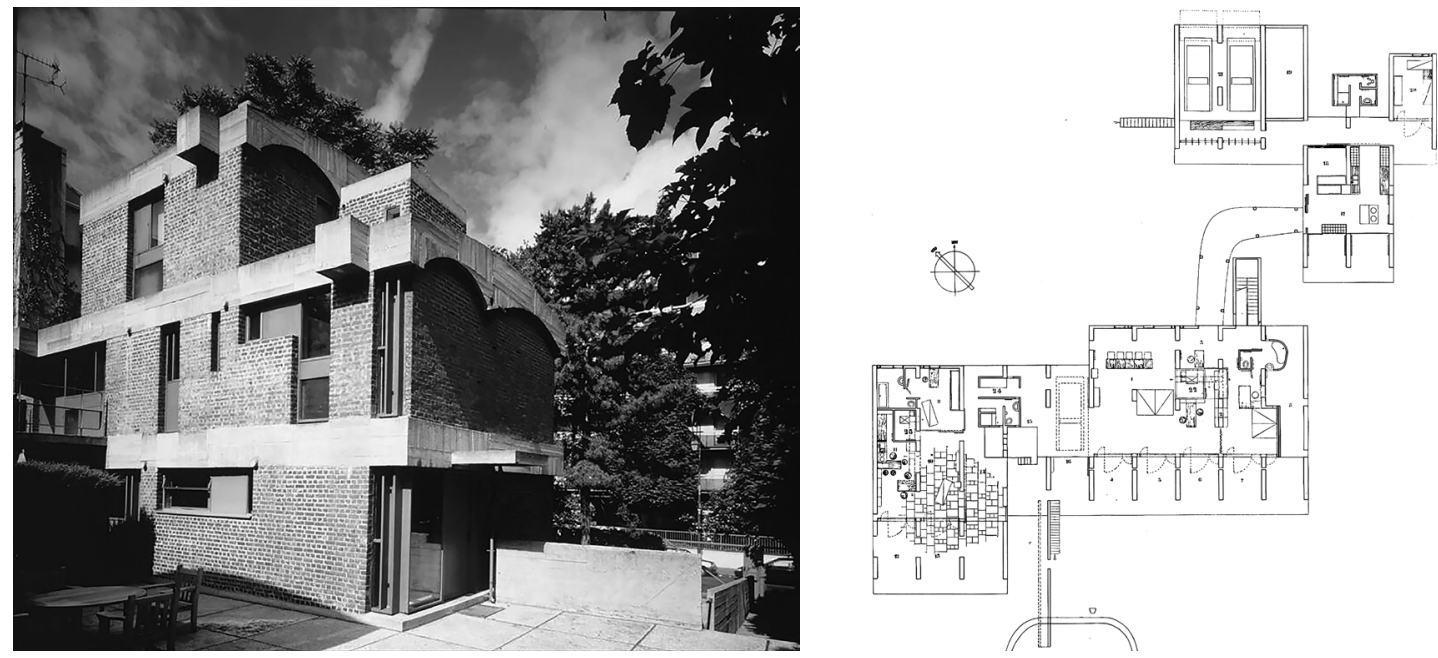

Fullaondo, ended with the Nueva Forma magazine and besotted the Architecture School of Madrid and some others got involved in the High-Tech that was popular at the same time Oíza left the ETSAM.

These academic trends were never built into a solid example of their principles. Some of them because they were mere graphic thoughts, others because Spain didn't have enough technological and industrial development at the time.

Opposite to these two failures -Deconstructivism and High-Tech- in the Architecture School of Madrid the discipline that stood out at the time was the tracing of the project in the plan as a method of projecting. A discipline that was defended by many of those that took over in the 60 s, the rear of the modern ideals of the beginning of the century.

Bourgeois Urban Expansion. The Moro House is located in Talavera de la Reina, Toledo, in Extremadura Avenue number 16, the old road that connected Madrid with Lisboa. Talavera is a town that emerged because of its strategic location, where the river Tajo passes through connecting the east with the west, an ideal place for commerce. The May and September Fairs started as a market for livestock but were still celebrated in the 20th Century at the Prado Gardens, in front of Nuestra Señora del Prado's Basilica, founded where the Romans built a temple for the pagan Pales and Ceres, the agriculture and animal husbandry protectors.

During the 40s, the first urbanistic project planned for Talavera was approved: the Ensanche del Ferial. (Fig. 6) The author of the project was the prolific Municipal Architect César Casado de Pablos (1918-1991). He organized a grid plan where the city 
Basílica de Nuestra Señora del Prado, fundada donde ya los romanos habían levantado un templo dedicado a los paganos Pales y Ceres, protectores de la agricultura y la ganadería.

En los años 40 se aprobó el primer proyecto de crecimiento urbano planeado de Talavera, el Ensanche del Ferial. (Fig. 6) El autor del plan fue el prolífico arquitecto municipal talaverano César Casado de Pablos (1918-1991). Ordenaba una trama 'hipodámica' de crecimiento al este, en una franja comprendida entre la avenida de Extremadura y la avenida de Pío XII, al norte. En la avenida de Extremadura, frente a los jardines y la basílica, en primera línea, el plan colocó una tira de hotelitos en parcelas de tamaño medio, de $25 \mathrm{~m}$ de fachada y $60 \mathrm{~m}$ de fondo, y no más de dos plantas. Este ensanche lo promueve la nueva burguesía liberal ligada al comercio emergente del desarrollismo autárquico. El medieval mercado de ganado se transforma en comercio burgués y dará lugar a una nueva ciudad, sobre la ruina y demolición de la ciudad histórica. La civitas nueva que necesitará de una urbs que la haga visible.

En la entrada desde Madrid, lo que antes fuera alameda se transformará en el Jardín del Prado, construyendo con dignidad el tránsito de lo rural a lo urbano. Aquí, frente a los jardines y la basílica, se sitúa la Casa Moro.

[Misión] Cobijo, palacio y ciudad. Al lado de la Casa Moro, Oíza había construido a principio de los sesenta la Casa Lucas Prieto. También iba a hacer la casa en el solar adyacente, de Pedro Moro. Los Moro eran parientes de don Vicente Saénz Vallejo, padre de Oíza. Para ellos ya había construido en 1950 la casa en el Risco. Pero quizás, la tardanza de Oíza -ocupado en Torres Blancas (1961-1968)- facilitó que Manuel de las Casas, nacido en Talavera y también ligado a los Moro, siendo estudiante tuviera ya dibujado el proyecto en 1963, unas sábanas de dibujos a lápiz que enseñaba con orgullo a todo aquel que visitaba su estudio en Arturo Soria.

Ambas casas (Fig. 7) comparten además de contemporaneidad, discreción, su casi nula presencia desde el espacio urbano. Discípulo y maestro cruzarían
Fig. 6. Ensanche del Ferial, Talavera de la Reina.

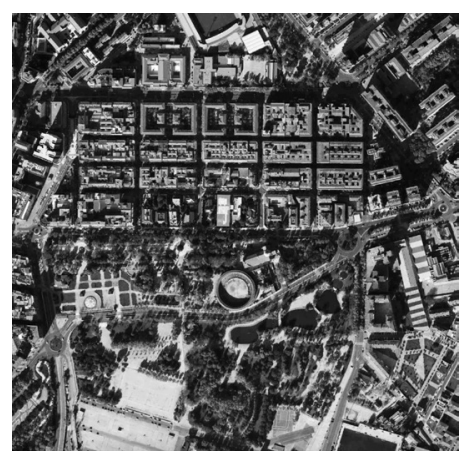

grew towards the east, along a strip between the Extremadura Avenue and the Pío XII Avenue to the north. At the Extremadura Avenue, in front of the Gardens and the Basilica, on the first row, the plan placed a series of medium-sized housing lots 25 metres front by 60 -metre-long, where only two floors could be constructed.

This city expansion was promoted by the new liberal middle-class linked to the emerging trade of autarkic developmentalism. The Medieval cattle market is transformed into bourgeois trade and will lead to a new city that arises over the ruins and demolition of the historic city. A new civitas that will need urbs to be shown.

Arriving from Madrid, what before was called an alameda will turn into the Prado Gardens, constructing with dignity the transition from rural into urban. Here, in front of the Gardens and the Basilica is where the Moro House is situated.

[Mission] Shelter, Palace and City. Next to the Moro House, Oíza had constructed, by the beginning of the 60s, his Lucas Prieto House. He was also supposed to create the house next to it for Pedro Moro. The Moro family were related to don Vicente Saénz Vallejo, Oíza’s father. He had already projected and constructed in 1950 de Risco House but maybe because of his delay -he was in the middle of the Torres Blancas construction (1961-1968)- the commission went to Manuel de las Casas. Since Manuel was born in Talavera and was also linked to the Moro family, by 1963, still a student, he managed to draw the project on his studio in Arturo Soria street. 


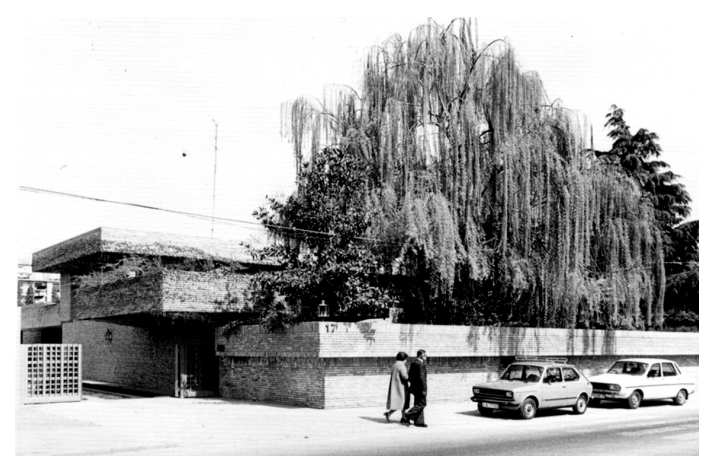

también sus caminos más tarde en proyectos como Orcasur (1978), o concursos como Zamora (1993), Fuencarral (1991) y Villaviciosa de Odón (1992).

El ideal orgánico del que está impregnada la casa Moro y el extenso programa familiar que debe resolver, hacen que su traza se organice como un árbol genealógico. La casa grande es un ideal clásico ya expresado en la idealizada traza de la villa romana de Vitrubio, utilizado también por Alberti y Palladio para explicar la ciudad como un simple cambio de tamaño de la compleja estructura doméstica de la casa, quien afirma: "La ciudad según sentencia de los filósofos es como una casa grande, y viceversa, la casa es una ciudad pequeña". (5) Idea que ya en el siglo xx Aldo van Eyck se apropia en su poema: "Un árbol es una hoja, una hoja es un árbol. Una ciudad es una casa. Una casa es una ciudad, y la ciudad una casa. Un árbol es un árbol, pero también una hoja enorme. Una hoja es una hoja, pero también un árbol en miniatura. Una ciudad no es una ciudad a menos que sea también una casa inmensa. Una casa es una casa solo si es también una pequeña ciudad". (6)

Aquí las preocupaciones no son las del das existenzminimum, confort ajustado, coste mínimo y seriación. No es una arquitectura social alejada de la opulenta burguesía, todo lo contrario, la Casa Moro es singular y específica. El amplio
Fig. 7. Comparativa, planta Casa Moro y planta Casa Lucas Prieto (1 Patio ingreso, 2 jardín estar, 3 patio juegos, 4 patio tendedero y garaje). Archivo Docomomo Ibérico.

Both houses (Fig. 7) share contemporaneity, discretion and almost no presence from the street. Disciple and master will later cross paths again in projects like Orcasur (1978), or architecture competitions such as Zamora (1993), Fuencarral (1991) and Villaviciosa de Odón (1992).

The organic ideal of which the Moro House is impregnated in, and the large family it must accommodate, makes the house organization become a genealogic tree. A big house is a classical ideal that started with Vitrubio's Roman Villa and was also used by Alberti and Palladio to explain the city as a simple change in scale of the complex domestic structure of the house. In their own words: "The city, as said by philosophers, is like a big house and vice versa, the house is a small city". (5) In the 20th Century Aldo van Eyck takes ownership of this idea in his poem: "A tree is a leaf; a leaf is a tree. A city is a house. A house is a city, and a city is a house. A tree is a tree, but also a huge leaf. A leaf is a leaf, but also a very small tree. A city is not a city unless it is also an enormous house. A house is a house only if it is also a small city". (6)

In Moro House, the main goals are not those of das existenzminimum, tight comfort, minimum cost or the arrangement in series. No, it is not a social architecture that escapes from the opulent bourgeois, quite the opposite, Moro House is a singular and specific house.

The big program is organized within a structural and composition system, construction of parallel walls that play with space while sliding with one another. The path and union of domestic protocols are always tangential. The transition be- 


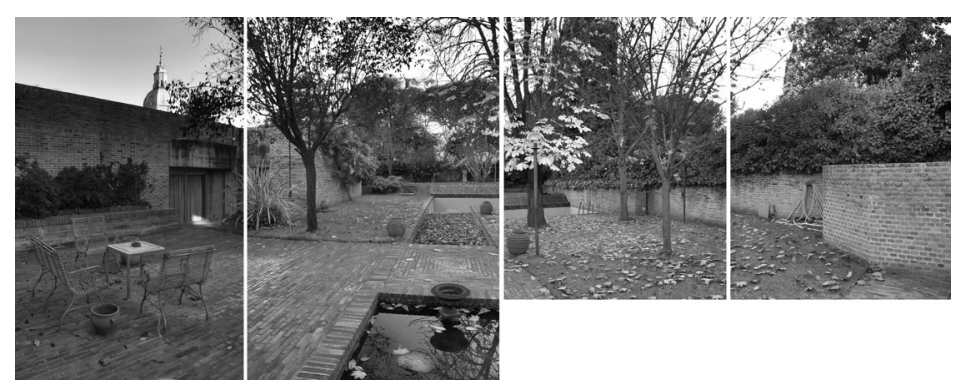

programa se organiza y alberga dentro de un sistema compositivo estructural, constructivo y espacial de muros paralelos que se deslizan entre ellos. El recorrido y concatenación de protocolos domésticos es siempre tangencial. La transición de uno a otro es insinuada, nunca evidente. Las circulaciones se comprimen entre muros hoscos de ladrillo visto, que siempre encuentran escape en la salida tangencial y diagonal hacia la luz.

$\mathrm{Al}$ exterior la casa no existe, se construye desde el interior, no tiene alzado, siguiendo el modelo de las casas patio romanas descritas por Vitrubio, tomando el tipo abstracto de las casas pompeyanas, como hombres y mujeres, todas iguales y todos diferentes. Es una arquitectura introvertida, con apego a la tierra, a la planta, que evoca la idea simbólica de cobijo, de orden domesticado a través de bancales artificiales que organizan el acuerdo con lo urbano y protegen frente a la entropía de la naturaleza. (Fig. 8)

[Morfología] La casa cuerpo. Está compuesta de crujías paralelas que definen 'órganos' articulados por patios que establecen sucesivos niveles de privacidad del espacio-tiempo doméstico en un recorrido ascendente y profundo. Entrando desde el sureste, al traspasar el umbral del portón, dejamos detrás, a la espalda, escondido, un estar de visitas. El vestíbulo, entre dos muros paralelos, es alargado y en penumbra con dos salidas al fondo; una insinuada a contraluz que, en diagonal, atravesando las estancias, remata la escenografía
Fig. 8. Casa Moro. Vista del patio sobre la Avenida Extremadura. Fotografía del autor, 2013.

tween one another is suggested, never obvious. The route is squeezed between rough walls of face bricks that always find an escape in the diagonal exit of light.

The house is built from the interior, it doesn't have elevations, following the model of the Roman Patio Houses described by Vitruvius or the typology of Pompeian Houses. It is like men and women, all the same, but all different. It is an introverted architecture, that bonds with the land, with the plan. It evokes the symbolic idea of shelter, of domesticated order by artificial terraces that organize the agreement with the urban space and protects against the entropy of Nature. (Fig. 8)

[Morphology] The Body-House. It is formed by parallel corridors that define articulated 'organs' created by patios with consecutive levels of privacy creating a domestic space-time circuit as you get deeper into the house.

Entering through the main entrance, in the south-east, we leave behind, nearly hidden, a sitting-room for visits. The lobby, between two parallel walls, is elongated and dark, with two exits at the end. One of the exits is only diagonally suggested because the light comes from the back, and it is completed by the elevated and panoptic 'mother's balcony'. The other one, narrower, darker and hidden, opens to the service area of the house (kitchen, office, laundry room, garage, etc.). The delayed position of this service area 'organ' opens to a front patio that gives some distance from the noisy National Road that passes through Talavera. 
en el elevado y panóptico 'balcón de la madre' elevado; la otra salida del vestíbulo, más estrecha, oscura y oculta, lleva a la zona de servicio de la casa (cocina, oficio, lavado y plancha, garaje, etc.). La posición retrasada en el solar del 'órgano' estar-cocina libera un patio delantero que pone distancia sobre la ruidosa carretera nacional que atraviesa Talavera. El patio, banqueado artificialmente a distintos niveles, gana altura suficiente en la tapia de fachada y consigue, desde el interior de la casa, que la vista se eleve por encima de la calle-carretera y conecte con los jardines y la Basílica del Prado. [ver figura 8] Lo urbano desaparece desde el interior, solo tienen presencia la naturaleza, la cúpula de la basílica y el cielo, el patio. Lo natural se domestica como representación del Jardín del Paraíso. Un jardín patio organizado en niveles y con trazado cardinal de arriates alrededor de la acequia-piscina, que utiliza el sistema compositivo islámico de jardín cuatripartito, el chahar bagh persa.

La planta, organizada también en un sentido ascendente hacia los ámbitos más privados, articula y cualifica los usos de los espacios a través de patios intermedios. El sentido ascendente hacia el fondo de la parcela permite, al tiempo que ocultar y ganar profundidad al espacio más privado, organizar un sótano de garaje e instalaciones, así como realizar el acuerdo entre la rasante de la avenida de Extremadura, más alta y a sur, con la calle Banderas de Castilla (Fig. 9) a norte, deprimida 1,15 m. Separada del estar por una galería-patio, en el fondo se organiza el 'órgano' de descanso, los dormitorios. Es una pieza alambicada, compacta y densa, que mirando a norte resuelve un programa de dormitorio de matrimonio y otros cinco dormitorios para los hijos con sus correspondientes piezas de servicio. La doble circulación, la ausencia de simetrías evidentes, la disposición oculta de las entradas a las alcobas, la gradación, como un velo de la fachada en diferentes ámbitos espaciales, terraza-galería-dormitorio, la complejidad que añade el trazado oculto, sinuoso y laberíntico, refuerzan su profundo carácter íntimo.

Alcobas de hacer y reposar, se diferencian espacialmente. La estancia es fluida, diáfana, de límites imprecisos. La zona de dormitorios es compacta, opaca y de vistas fragmentadas. Son las dos posibilidades que permite la diagonal
Fig. 9. Casa Moro. Secciones transversales, plano n. 7 del proyecto de ejecución, abril 1967. Archivo Manuel de las Casas.

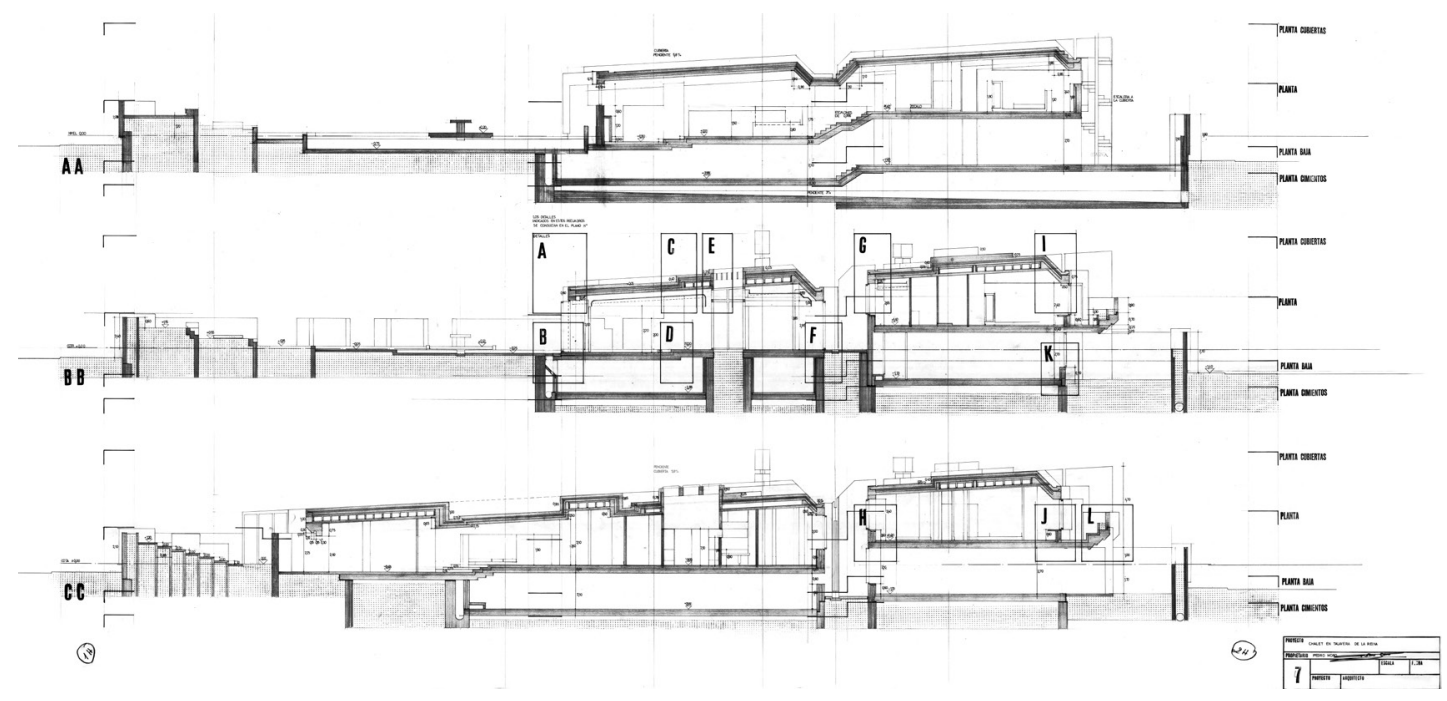




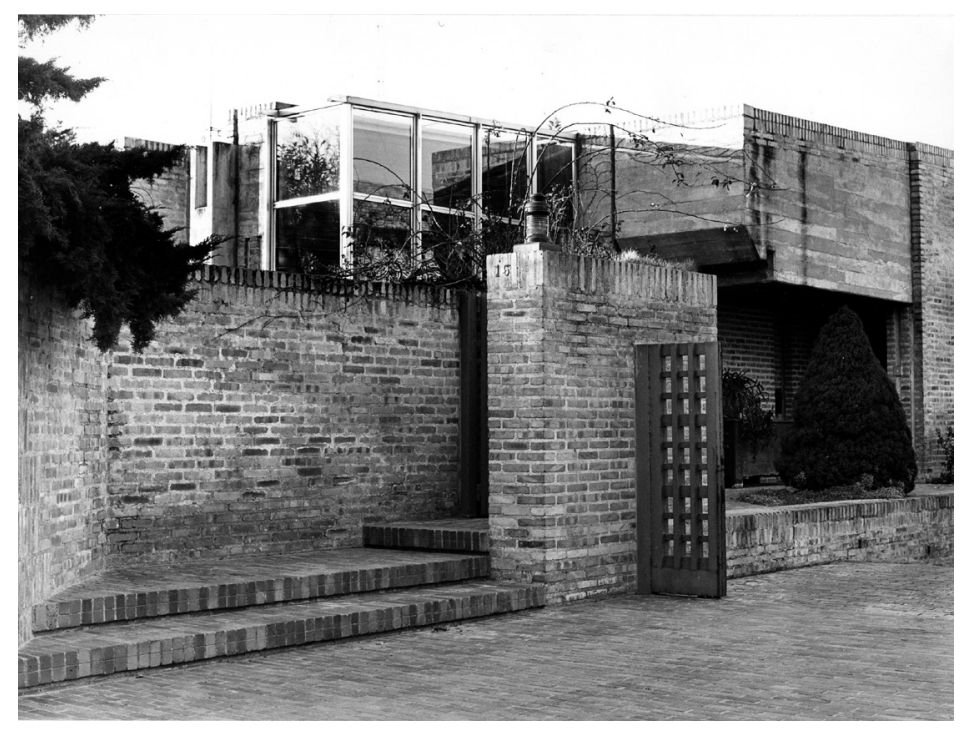

puesta al servicio de ordenar y cualificar los espacios, alargar las distancias en las zonas más públicas o quebrarlas en las más secretas. Diagonal que asoma a la calle para hacer la entrada en recodo, pequeña y apretada, (Fig. 10) como la entrada al laberinto que oculta a Pasífae.

[Métrica] Múltiplos de cinco. El solar, alargado y profundo en dirección norte-sur, mide 26 metros de fachada por 62,10 metros de fondo, $1.614,6 \mathrm{~m}^{2}$. La profundidad como característica específica del lugar será utilizada en la cualificación y concatenación de los diferentes ámbitos domésticos. La casa es un ejercicio de gradación de distancias, de dominio del juego escenográfico con las profundidades de campo. Se retranquea de los linderos, 3,45 m al oeste y 4,35 m en la entrada al este, compartida con la casa Lucas Prieto. [ver figura 7]
Fig. 10. Casa Moro. Acceso desde el sur. Fotografía de Luis Casals. Publicada en El Croquis, n. 15-16, 1984, p. 10.

The patio, divided artificially into different levels, has a tall facade wall that, from the interior of the house, lets you see over the street-road and connects you with the Gardens and the Prado Basilica. [see figura 8] From the interior only nature is shown, urbanization disappears, the viewer only sees the Basilica's dome, the sky and the patio. Nature is domesticated like a representation of the Paradise Garden. A patio-garden organized in levels and with a cardinal outline made of flowerbeds that go around the swimming pool ditch and uses an Islamic composition system dividing the garden into four spaces: the Persian Chahar Bagh. The plan, also organized in an ascendant way to the private areas, articulates and qualifies the use of spaces through intermediate patios. The ascendant way to the end of the plot allows the private space to be hidden and deep. It also allows the organization of a basement for the garage and installations, and to create a union between a taller slope in the southern Extremadura Avenue and a more sunken $(1,15 \mathrm{~m})$ in the northern Banderas de Castilla Street. (Fig. 9) The bedrooms, the resting organ of the house, are organized at the back, separated from the sitting-room by a patio-gallery. It is an obscure, compact and dense piece that, facing north, solves a structure of one main bedroom and five other bedrooms for the children with their corresponding bathrooms. The double circulation, the absence of obvious symmetries, the hidden arrangement of the entrance to the bedrooms, the graduation on the facade, like a veil, of the different spaces, terrace-gallery-bedroom, the complexity of the hidden and labyrinthine outline... all of that reinforces its deeply private character.

The rooms used to 'make' and to 'rest' are distinguished even spatially. The room to 'make' is fluid, clear, of ambiguous limits. The rooms to 'rest' are compact, obscure and with fragmented views. These are the two options that allow the neat diagonal stretch distances between the most public parts of the house and the most private ones. The diagonal 

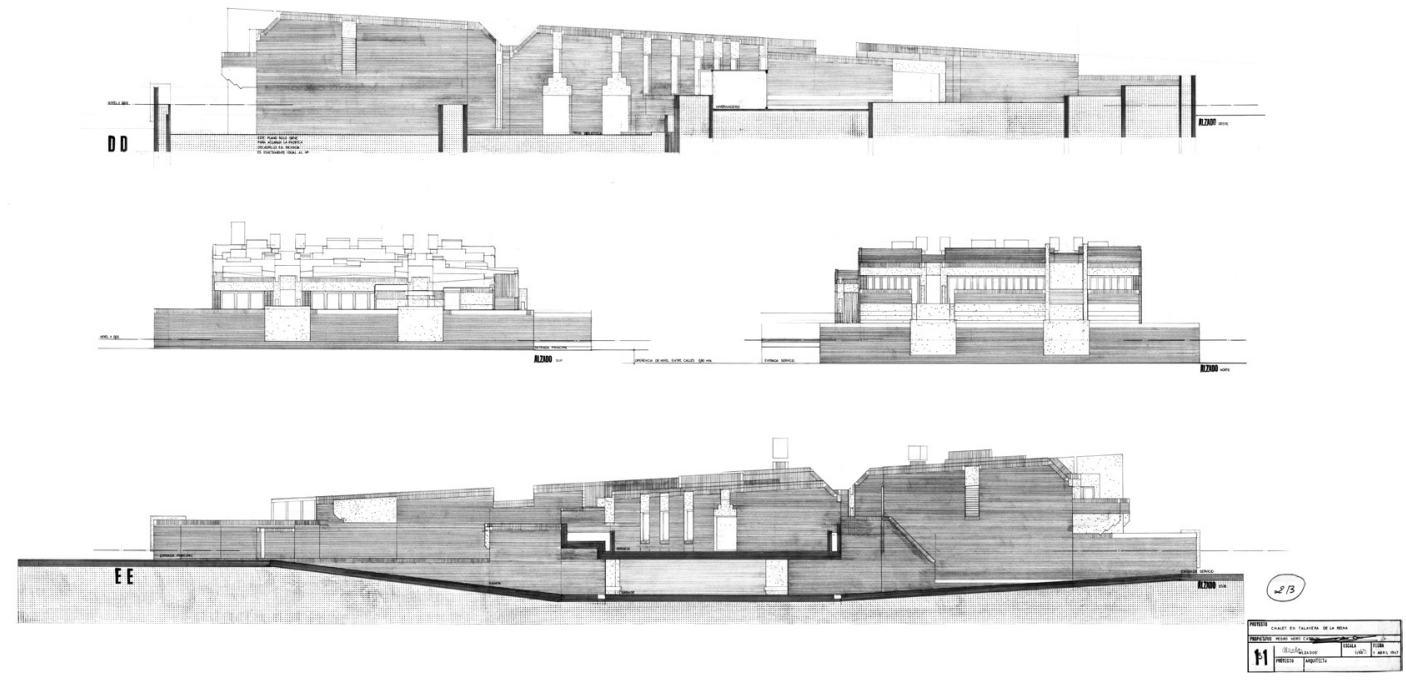

La casa está contenida en un trazado de muros paralelos que definen crujías fáciles de alzar y cubrir con la construcción tradicional. (Fig. 11) La armonía de crujías paralelas de la Casa Moro sigue, entre ejes de muro, el ritmo: 310 / 225 / 565 / 225 / 310 / 140 cm. Las trazas de los muros de carga, de tres hojas de media hasta, definen un ancho de muro de $55 \mathrm{~cm}$, los dos pies de la construcción tradicional, un lenguaje de muros gruesos y huecos profundos. Si descontamos el grueso de muros, en luces de uso libres el ritmo es: 255 / 170 / 510 / 170 / 255 / 85. El aparejo de las fábricas impone una métrica sometida por un lado a las dimensiones del ladrillo y por otro a las dimensiones de uso doméstico. 255 es una buena medida para una alcoba y 510 permite una estancia generosa, o dividida a la mitad (255) transformarse en dos; 85 y 170 permiten el paso estrecho y desahogado respectivamente.
Fig. 11. Casa Moro. Alzados, plano n. 11 del proyecto de ejecución, abril 1967. De arriba abajo y de izquierda a derecha: alzado medianera oeste, alzado fachada sur, alzado trasero norte, alzado-sección medianera este. Archivo Manuel de las Casas.

sticks out to the street to make the entrance inside twisted, small and tight, (Fig. 10) like the entrance of the labyrinth that hides Pasífae.

[Metrics] Multiples of Five. The elongated and deep plot, oriented north-south, measures 26 metres in the facade by 62,10 metres long, $1614,6 \mathrm{~m}^{2}$ in total. Depth, as a specific characteristic of the place, will be used to qualify and link the different domestic spheres. The house becomes an exercise of intensities between distances, of ability in the game between the set design and the depth of the plot. Boundaries are set back 3,45 $\mathrm{m}$ to the west and $4,35 \mathrm{~m}$ in the entrance to the east, like the Lucas Prieto House. (Fig. 7)

The house is contained in between the layout of the parallel walls that defines a series of bays that allow simple traditional construction. (Fig. 11) The parallel harmony created by these distributions in the Moro House follows the next rhythm between wall axes: 310 / 225 / 565 / 225 / $310 / 140 \mathrm{~cm}$. The brick structure imposes a certain size that comes with the brick scale and the dimensions needed for domestic use of the spaces. $255 \mathrm{~cm}$ is a good bedroom size and $510 \mathrm{~cm}$ allows for a more generous room. Dividing it in half (255) transforms it into two spaces; 85 and 170 allows a narrow and wider passage.

The frontal and focused rigidity imposed by two parallel walls changes into a fluid space as the diagonal walls start to appear. This diagonal interlinking adds depth and ambiguity to space. It's a simple action on an elemental and classical construction 


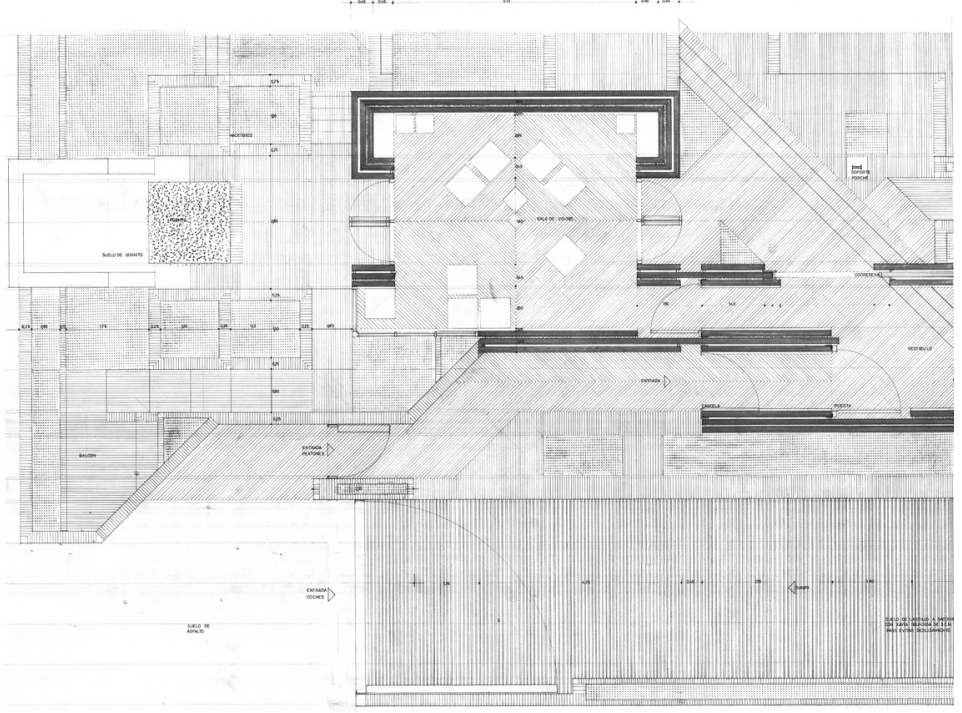

La rigidez frontal y focalizada que imponen dos muros paralelos se transforma en fluidez espacial con la interrupción de los muros en diagonal y su aparición seriada en el espacio. La concatenación en diagonal añade profundidad y ambigüedad al espacio. Se trata de una operación sencilla sobre un sistema constructivo clásico elemental, una operación geométrica que incorpora complejidad espacial al multiplicar las visuales, alargar las distancias y transformar el espacio unidireccional de los muros paralelos en espacio fluido y multi-perspectivo, de abundantes visuales.

Esta operación de interrupción de los muros también mejora la versatilidad espacial. La rotura permite sumar dos crujías y se pueden solucionar ámbitos domésticos de otras medidas como la cocina o el 'balcón de la madre', o en la zona de dormitorios conseguir una galería común.
Fig. 12. Casa Moro. Detalle puerta de entrada, plano n. 23 del proyecto de ejecución, abril 1967. Archivo Manuel de las Casas.

system, a geometrical process that creates spatial complexity by multiplying the visual fields. The distances are enlarged, and the unidirectional space is transformed by the parallel walls into a fluid multi-perceptive space with many points of view.

This action of interrupting the walls also helps to improve spatial versatility. The crack allows to add up two bays so that different size domestic rooms can be created such as the kitchen, the 'mother's balcony', or the gallery on the bedroom area.

[Matter] In Raw State. "It cannot have been so very different in Ur 5000 years ago: the same bricks laboriously-crafted [...] the same spaces around the courtyard, the same fence, the same sudden transition from light to dark, the same cold after the heat, the same starry nights, maybe the same fears, the same dreams". Aldo van Eyck (7)

The honest expression and the constructive economy subordinated to the constructive order that the brick metric construction imposes, and the few types of materials, will be, since this debut, a constant in Manuel de las Casas works. (Fig. 12)

The Moro House is built with vernacular techniques and materials: solid bricks and local construction companies. Triple walls, a reinterpretation of the cavity wall, curb floors or even the roof made out of the same solid brick. The brick constructive system is completed using certain lintel bending elements made out of reinforced concrete of big dimensions. The parallel wall structural system is formed by triple cavity walls made out of half-foot brick. (Fig. 13) 
[Materia] En estado crudo. "No debió de ser muy distinto en Ur hace 5.000 años: los mismos ladrillos creados laboriosamente... los mismos espacios alrededor de un patio, el mismo cercado, la misma transición repentina de la luz a la oscuridad, el mismo frío después del calor, las mismas noches estrelladas, tal vez los mismos miedos, el mismo sueño". Aldo van Eyck. (7)

La expresión honesta y la economía constructiva subordinada al orden constructivo que impone la métrica y la disciplina del aparejo de ladrillo, de pocos materiales será también, desde esta opera prima, una constante en la obra de Manuel de las Casas. (Fig. 12)

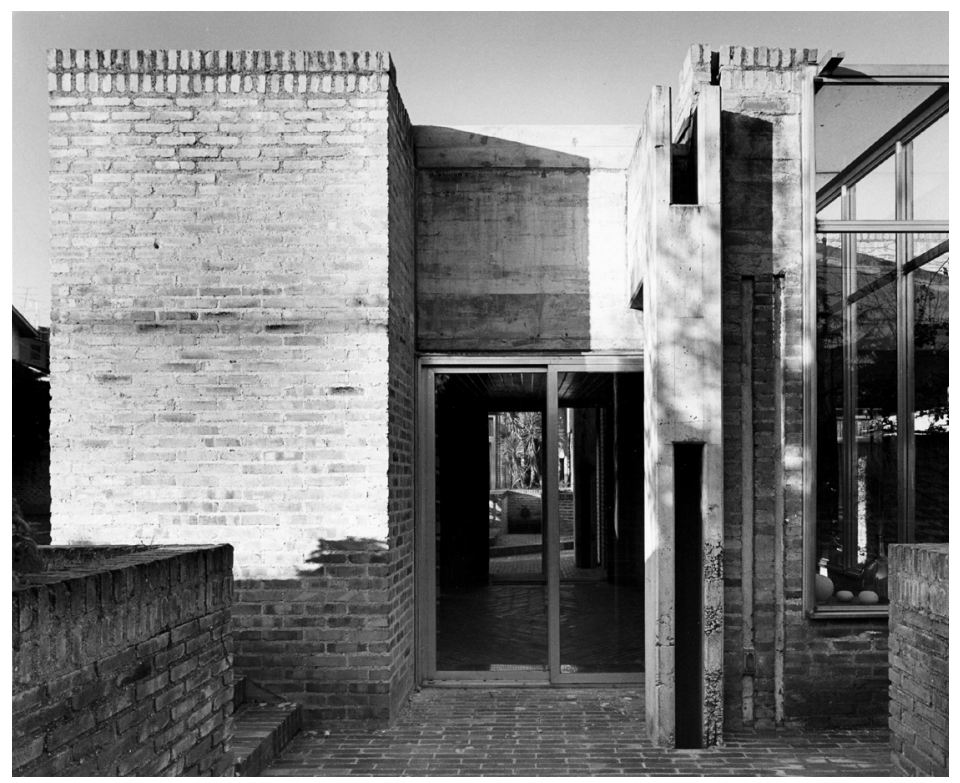

Fig. 13. Casa Moro. Patio estancia invitados, acceso. Fotografía de Luis Casals. Publicada en El Croquis, n. 15-16, 1984, p. 10.

The system allows solving independently, in each cavity between walls: water impermeability by applying water-repellent mortar in the exterior face and thermal insulation with agglomerated cork panels in the interior. The flat accessible roof of the project is solved as a floor were the brick works as heavy protection for the insulation. The brick can solve floors and walls with a constructive system inherited from the 'total brickwork' recommended by Moya during the post-war constructions and interpreted in a modern, brutalist way.

Once Team X put an end to the Modern Movement with the last CIAM, the X of 1956, a new period will start where the modernity will be revised, and new forms will appear. The material will now be used in its raw state and the construction systems will let the naked materials express themselves. This will be the identity of this new order called New Brutalism, versus the Formal Brutalism divulged by Reyner Banham, author of the article 'The New Brutalism' in the Architectural Review in 1955. (8) A groundswell that ethically starts with the Art Exposition This is Tomorrow (1956), (9) where Group 6 (A. y P. Smithson, N. Henderson y E. Paolozzi) and their Patio \& Pavillion runs through the Dadaist beauty of the objects. A criticism of the unspoiled composition of the classical tools inherited from the International Style. (Figs. 14 and 15)

[Method] Epilogue. The Moro House is based on a simple system of parallel walls that organize a complex interior and plays with the lights and shadows. Although it uses an archaic constructive and compositional system, the diagonal point of view frees the space from the typical four-wall box. An architecture based on the tradition of the courtyard house, a 
La Casa Moro está construida con materiales y técnicas vernáculas: de ladrillo macizo, y por empresa local. Los muros triples, reinterpretación del cavity wall anglosajón, los suelos de sardinel e incluso la cubierta se resuelven con la misma pieza cerámica de ladrillo macizo. El sistema de construcción cerámica se completa con la utilización en los elementos a flexión de piezas adinteladas de hormigón visto de grandes dimensiones. El sistema estructural de muros paralelos está formado por muros capuchinos triples de ladrillo de medio pie de espesor. (Fig. 13)

El sistema permite resolver de forma independiente, en cada una de las cámaras de separación que se forman entre las tres hojas: la estanqueidad al agua con un enfoscado hidrófugo en la cámara exterior ventilada y el aislamiento térmico con planchas de corcho aglomerado en la cámara interior. La cubierta accesible y transitable en el proyecto, se resuelve como un suelo en el que la fábrica de ladrillo hace de protección pesada de la impermeabilización. El ladrillo es capaz de resolver suelos y fábricas, sistema constructivo herencia de la 'albañilería total' recomendada por Moya en la precaria construcción de postguerra, interpretada en contemporánea clave brutalista.

Finiquitado el Movimiento Moderno por los ponentes del Team X en el último CIAM, el X de 1956, comenzará una etapa de revisión desde dentro de la modernidad que dará lugar a nuevas formas. El uso en toda la crudeza natural del material y de los sistemas constructivos, desnudos sin ropajes, permitiendo que la materia hable por sí misma serán una seña de identidad del nuevo orden emergente, el Nuevo Brutalismo, frente al brutalismo formal divulgado por Reyner Banham, autor en 1955 del artículo 'The New Brutalism' en Architectural Review. (8) Una corriente que tiene su origen ético en la exposición de arte de 1956 This is Tomorrow 1956, (9) donde el Grupo 6 (A. y P. Smithson, N. Henderson y E. Paolozzi) con el Patio \& Pavillion se adentraban en la belleza dadaísta de los objetos, en la crítica a la impoluta composición de herramientas compositivas clásicas que había heredado el Estilo Internacional. (Figs. 14 y 15)

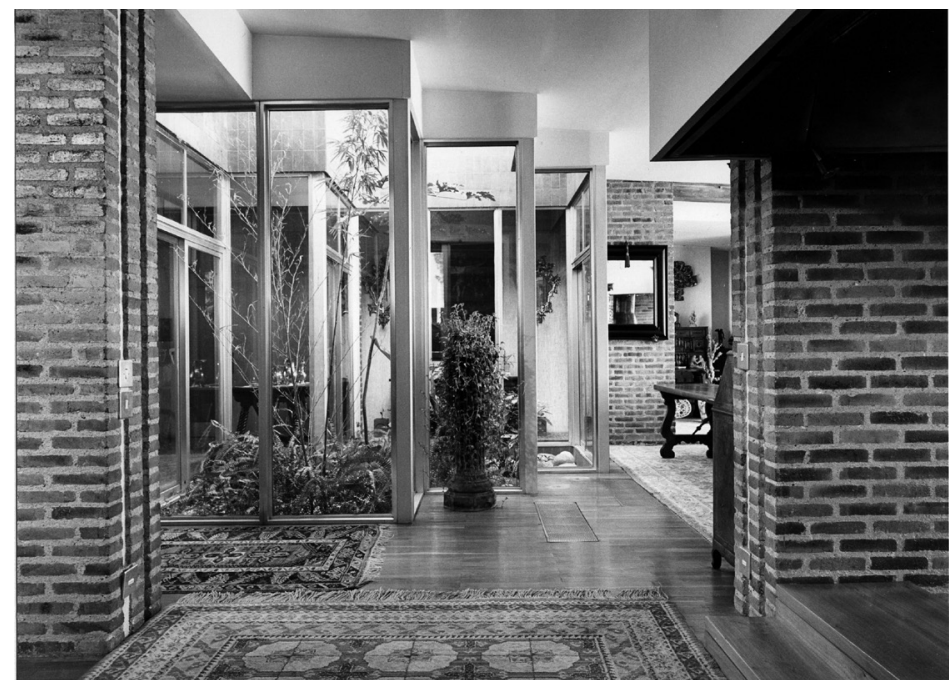

Fig. 14. Casa Moro. Patio interior. Fotografía de Luis Casals. Publicada en El Croquis, n. 15-16, 1984, p. 11.

Fig. 15. Casa Moro. Galería en la estancia frente al patio. Fotografía de Luis Casals. Publicada en El Croquis, n. 15-16, 1984, p. 11.

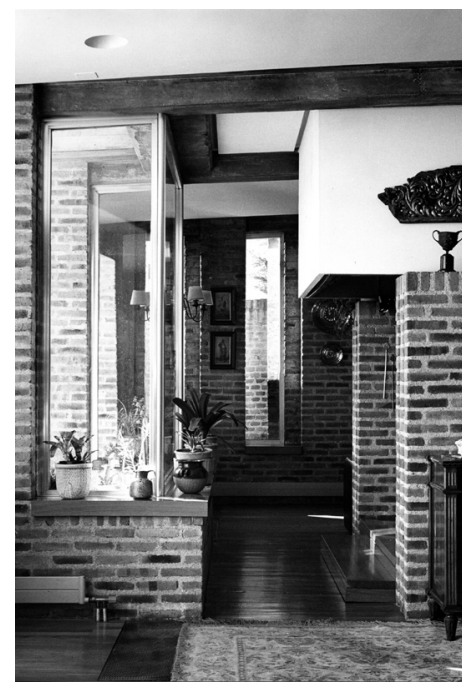


[Método] Epílogo. La Casa Moro es un sistema sencillo de muros paralelos que organiza un interior complejo y corpóreo de penumbras y contraluces. Un sistema constructivo y compositivo arcaico, donde el sesgo diagonal libera al espacio de las ataduras clásicas de la caja de muros y vanos recortados. Una arquitectura anclada en la tradición del hogarpatio, casa detrás de una tapia, influenciada por el alambicado espacio intimista hispano-musulmán, que se contamina de las influencias de los maestros del movimiento moderno y de los ideales de su tiempo, donde el arquitecto se sirve de la diagonal para, en un hecho paradójico, contradictorio con el sistema ortogonal, en una impureza, transformar como prestidigitador un sistema; racional y cartesiano, en un complejo espacio orgánico sustentado en la geometría, en la economía y en la construcción al servicio de la composición.

Manuel de las Casas elige la diagonal como un sastre elegiría el bies de la tela por ser la dirección más elástica del tejido, la que forma pliegues suaves y mejor se adapta sin esfuerzo a las formas del cuerpo. Construye una sofisticada casa cuerpo. El sesgo no es gratuito, en unos casos alarga las perspectivas, y el espacio se agranda en torno al hogar; otras veces se utiliza para ocultar las vistas directas sobre los espacios más privados y aísla la casa de los medianeros próximos. Un continuo juego espacial de enseñar y esconder manejando la escala de un complejo y amplio programa, sin perder en ningún momento la referencia al tamaño del confort doméstico, la Casa Moro se convierte así en un rico y sofisticado recorrido interior, en representación a menor escala de una ciudad. Esta complejidad es alcanzada con formas sencillas, desde el dominio del trazado en planta, invariante que permanecerá a lo largo de toda su obra, a lo largo de todas sus plantas. Un método, proyectar desde la planta, que fue referente en la enseñanza de la arquitectura en la Escuela de Madrid del último tercio del siglo xx.

house behind a wall, influenced by the framed intimate spaces of the Hispanic-Muslim tradition. It is also contaminated by the Modern Movement masters and the ideas of that time. The architect uses the diagonal to, as a paradox and opposite to the orthogonal system, transform, as if he were a magician, the rational system into a complex organic space based on geometry, economy and construction that serves the composition.

Manuel de las Casas chooses the diagonal as a tailor chooses the bias of the fabric because it is the most elastic direction of the fabric that best adapts to the form of the body. He constructs a sophisticated body-house. This bias-view of the space, created sometimes, enlarges the perspective and gathers it around the home, but, other times, it is used to hide the direct view over private spaces and isolates the house from the neighbours. A constant special game of hide-and-seek where the scale is used to distribute a wide and complex program, never losing the perfect size of the domestic comfort needed in each space. The Moro House is turned into a sophisticated and rich interior tour as if it were a small city. The complexity is achieved with simple forms and comes from the plan's trace, invariant that will remain throughout his entire work in all his plans. A method, projecting from the plan, that will be a reference in the teaching of architecture at the Architecture School of Madrid through the last third of the 20th Century. 


\section{NOTAS}

1. Desde 1964 a 1972, al terminar los estudios de arquitectura, Manuel de las Casas se inicia en el ejercicio de la profesión con los compañeros de curso Javier Seguí de la Riva y Santiago López Hernández como colaboradores, con quienes comparte autoría en la Casa Moro. Una etapa de transición marcada por la influencia del tardo-organicismo en el contexto académico, y el tránsito hacia la depuración formal y la simplificación. Mutación que se materializa en el proyecto del Colegio de Internas de Talavera de la Reina (1975). De esta primera época destacan obras como las casas en Buitrago (1967), el Colegio en Medina del Campo (1969), y la 'casa sobre una roca' en Galapagar (1969). En la Casa Moro, encontramos recurrentes compositivos, tectónicos e intelectuales que de una manera u otra aflorarán posteriormente en la obra de Manuel de las Casas, que sin embargo se disiparán en la obra de Javier Seguí que deriva hacia el surrealismo gráfico y la de Santiago López, que destacaría a finales de los setenta en otras disciplinas artísticas.

2. "Ya se ha observado también cómo, cuando en Madrid triunfaba la arquitectura moderna de la mano de una generación a la que hubiera correspondido ya heredarla, en la cultura arquitectónica occidental se producía con gran fuerza una importante revisión que, vía el eco de Bruno Zevi, interpretaba al 'estilo internacional' como la fase revolucionaria, pero 'infantil', de la arquitectura moderna. La verdadera maduración y desarrollo de solo podría tener lugar, según Zevi, si se perseguía el ideal orgánico, [...] Cuando los arquitectos madrileños hoy más reconocidos llevaron adelante el ideal moderno a partir de aquellos años, irán en su búsqueda lastrados por un difícil equívoco; esto es, armados con unos pertrechos intelectuales que superponían la ambición de insertarse en la arquitectura moderna propiamente dicha con la de ser pronto muy proclives a la citada revisión orgánica que, ahora paralelamente, les llega de fuera". En: CAPITEL, Antón. 'La aventura moderna de la arquitectura madrileña'. Arquitectura, n. 237, VII-VIII, Madrid: COAM, 1982, p. 11. 3. "La figura en quien se miran todos estos jóvenes arquitectos es, y no pienso que nadie lo ponga en duda, Alejandro de la Sota, quien permaneció impasible y solo, ajeno a los desviacionismos de sus compañeros de generación y que ahora vería así premiada, con la admiración de los más jóvenes, su obstinada postura. A nuestro entender giran en esta órbita obviamente López-Cotelo, Puente y Azofra, discípulos directos, pero su influencia se hace sentir en otras gentes como son los Casas, $\mathrm{o}$ aparece en el proyecto de vivienda unifamiliar de López-Peláez, Frechilla y Sánchez, llegando las salpicaduras hasta los propios colaboradores de Oíza, López-Sardá, Valdés, Vellés y Velasco". En: MONEO, Rafael. '28 arquitectos no numerarios'. Arquitecturas Bis, n. 23, Madrid: La Gaya Ciencia S. A., 1978, pp. 22-24.

4. “Otra investigación siguió: para restablecer el contacto con los materiales nobles y fundamentales de la arquitectura: el ladrillo, amigo del hombre; hormigón áspero, un amigo también; con revestimientos, amigos del hombre; la presencia de colores intensos que provocan alegría, etc [...] La composición se ha servido de hacer aberturas en estos muros, todos paralelos, jugando llenos contra vacíos, pero jugando intensamente el juego arquitectónico". En: JEANNERET, Pierre, Le Corbusier. 'Maison d'Habitation de Mrs. Manorama Sarabhai, Ahmedabad, 1955'. Ouvre complète 1952-1957. Zurich: W. Boesiger, Ed. Les Editions dÁrchitecture, p. 115.

5. ALBERTI, León Batista. De Re Aedificatoria. Florencia, 1485, Libros I y IV. $1^{a}$ versión castellana: Madrid, 1582. Ed. Facsímil en Albatros Ed., Valencia, 1977, Libro primero, p. 22.

Andrea Palladio en su Cuatro Libros sobre Arquitectura repite la misma idea: "Y finalmente al elegir los sitios para la construcción de la Villa se han de hacer aquellas consideraciones que se hicieron para elegir el sitio para la ciudad: puesto que la ciudad no es otra cosa que una casa grande y, al contrario, la casa grande una ciudad pequeña".

6. LIGTELIJN, Vicent. Aldo van Eyck. Works. Basilea: Birkhäuser

Publishers, 1999, p. 49.

7. Citado en: HERTZBERGER, Herman; VAN ROIJEN-WORTMANN, Addie; STRAUVEN, Francis. Aldo van Eyck Amsterdam: Stichting Wonen/van Loghum Slateurs, 1982, p. 47.
NOTES

1. From 1964 to 1972 , when he finished his architecture studies, Manuel de las Casas starts working with his classmates: Javier Seguí de la Riva and Santiago López Hernández, with whom he shares the authorship of Moro House. A transition phase with a clear influence of the late organicism in the academic context, and the transition to a formal depuration and simplification. This mutation will be materialized in the Boarding School project in Talavera de la Reina (1975). From this first period some works stand out such as the houses in Buitrago (1967), the school in Medina del Campo (1969), and the 'house on top of a rock' in Galapagar (1969). In Moro House we find some compositive, tectonic or intellectual constants that will be present in one way or another throughout all Manuel de las Casas' trajectory. However, Javier Seguí will lead to a graphic surrealism and Santiago López will outstand in the late seventies in other artistic disciplines.

2. "It has already been pointed out how Modern Architecture was succeeding in Madrid with the work of a generation that should, in fact, be inheriting its influence. In the architectonic occidental culture, a big force of revision was being created, with the echo of Bruno Zevi, who understood the International Style as a revolutionary but childish phase of Modern Architecture. He said that, the real maturity and development of this, should only take place if the organic ideal was followed, [...]. When those architects from Madrid, nowadays renowned professionals, started working with the modern ideal of those years, they would fall into a big mistake: their intellectual tools were used with the ambition of matching with the formal Modern Architecture, trying to be open to the organic revision, but this revision came parallel from the outside”. In: CAPITEL, Antón. 'La aventura moderna de la arquitectura madrileña'. Arquitectura, n. 237, VII-VIII, Madrid: COAM, 1982, p. 11.

3. "The personality all of these young architects are looking up to is, and I hope nobody doubts it, Alejandro de la Sota, who stayed unaffected, alone and unconnected to the detours of his fellow peers of the same generation. He would later see that this obstinate position had a reward in the admiration of all those young architects. We understand that this disciples we are talking about are, obviously, López-Cotelo, Puente and Azofra, but his influence goes far beyond and it can be seen in the work of other people such as the Casas family, or López-Peláez, Frechilla and Sánchez with their project for single-family housing, even influencing people who collaborated with Oíza, LópezSardá, Valdés, Vellés and Velasco". En: MONEO, Rafael. '28 arquitectos no numerarios'. Arquitecturas Bis, n. 23, Madrid:

La Gaya Ciencia S.A., 1978, pp. 22-24.

4. "Another investigation followed: to restore the contact with fine and fundamental materials of architecture: The brick, friend of man; rough concrete, also a friend of man; different coatings, friends of man; the presence of intense colours that gives joy... [...] Compositions has been used to make openings on these walls, all parallel, full and empty spaces playing, but playing the architecture game intensly". In: JEANNERET, Pierre, Le Corbusier. 'Maison d'Habitation de Mrs. Manorama Sarabhai, Ahmedabad, 1955'. Ouvre complète 1952-1957. Zurich: W. Boesiger, Ed. Les Editions dÁrchitecture, p. 115.

5. ALBERTI, León Batista. De Re Aecdificatoria. Florencia, 1485, Books I y IV. 1st spanish version: Madrid, 1582. Ed. Facsímil in Albatros Ed., Valencia, 1977, First book, p. 22. Andrea Palladio repeats the same idea in The Four Books on Architecture: "And finally, when choosing the places for the construction of the villa, it should be considered the same factors as in choosing the place for the city: because a city is nothing else than a big house, and the other way around, a big house is nothing else than a small city".

6. LIGTELIJN, Vicent. Aldo van Eyck. Works. Basilea: Birkhäuser

Publishers, 1999, p. 49.

7. Quote in: HERTZBERGER, Herman; VAN ROIJEN-WORTMANN, Addie; STRAUVEN, Francis. Aldo van Eyck. Amsterdam: Stichting Wonen/van Loghum Slateurs, 1982, p. 47. 
8. "Reyner Banham, redactor de la revista Architectural Review y miembro del Idepent Group, se convierte a lo largo de los años sesenta en el crítico de arquitectura más convencido, defensor y promotor de las corrientes de alta tecnología en arquitectura, al unísono con la presentación de las nuevas ideas del grupo Archigram”. Citado por HEREU, Pere; MONTANER, Josep María; OLIVERAS, Jordi. 'El Brutalismo y La Atlántida de Hormigón, Megaestructuras'. Textos de arquitectura de la modernidad. Nerea, 1994, p. 359. Reyner Banham es autor de Megaestructuras. Futuro urbano del pasado reciente. Barcelona: Gustavo Gili, 1978.

9. “Todo análisis acerca del Brutalismo estará errado si no toma en cuenta la tentativa brutalista de ser objetiva respecto de la "realidad", de los fines culturales de la sociedad, de sus necesidades, de sus técnicas, etc. El Brutalismo trata de enfrentarse con una sociedad signada por la producción masiva y de extraer una áspera poesía de las fuerzas confusas y poderosas que la caracterizan. Hasta ahora, el Brutalismo ha sido analizado estéticamente, cuando en realidad su esencia es ética”. En: SMITHSON, Alison y Peter. 'The New Brutalism'. Architectural Design, n. ${ }^{\circ}$, abril, 1957, p. 113.

\section{REFERENCIAS}

CASAS, Manuel de las. 'Casa Pedro Moro’. El Croquis, n. 15-16, 1984, pp. 9-11.

CASAS, Manuel de las. 'Vivienda unifamiliar en Talavera de la Reina'. Boden, abril, 1976, pp. 14-16.

CASAS, Manuel de las. 'Vivienda Moro'. Arquitectura contemporanea. Toledo: Colegio Oficial de Arquitectos de Castilla-La Mancha, 1995, pp. 208-211.
8. "Reyner Banham, editor of Architectural Review magazine and member of the Idepedent Group, will become during the $60 \mathrm{~s}$, the most convinced, defender and promoter architecture critic of the high-tech currents in architecture, in unison with the presentation of the new ideas exposed by the Archigram group". QuoteD by HEREU, Pere; MONTANER, Josep María; OLIVERAS, Jordi. 'El Brutalismo y La Atlántida de Hormigón, Megaestructuras'. Textos de arquitectura de la modernidad. Nerea, 1994, p. 359. Reyner Banham is the autor of: Megastructures. Urban futures of the recent past. Barcelona: Gustavo Gili, 1978.

9. "Any discussion of Brutalism will miss the point if it does not take into account Brutalism's attempt to be objective about 'reality' -the cultural objectives of society, its urges, and so on. Brutalism tries to face up to a mass-production society, and drag a rough poetry out of the confused and powerful forces which are at work. Up to now, Brutalism has been discussed stylistically, whereas its essence is ethical". In: SMITHSON, Alison and Peter. 'The New Brutalism', Architectural Design, n. 27, April, 1957, p. 113.

\section{REFERENCES}

CASAS, Manuel de las. ‘Casa Pedro Moro'. El Croquis, n. 15-16, 1984, pp. 9-11.

CASAS, Manuel de las. 'Vivienda unifamiliar en Talavera de la Reina'. Boden, abril, 1976, pp. 14-16.

CASAS, Manuel de las. 'Vivienda Moro'. Arquitectura contemporanea. Toledo: Colegio Oficial de Arquitectos de Castilla-La Mancha, 1995, pp. 208-211. 